University of Nebraska - Lincoln

DigitalCommons@University of Nebraska - Lincoln

\title{
Geologic setting and stratigraphy of the Ziegler Reservoir fossil site, Snowmass Village, Colorado
}

Jeffrey S. Pigati

U.S. Geological Survey, Denver Federal Center, jpigati@usgs.gov

Ian M. Miller

Denver Museum of Nature and Science

Kirk R. Johnson

Denver Museum of Nature and Science

Jeffrey S. Honke

U.S. Geological Survey, Denver Federal Center

Paul E. Carrara

U.S. Geological Survey, Denver Federal Center

See next page for additional authors

Follow this and additional works at: https://digitalcommons.unl.edu/usgsstaffpub

Part of the Geology Commons, Oceanography and Atmospheric Sciences and Meteorology Commons, Other Earth Sciences Commons, and the Other Environmental Sciences Commons

Pigati, Jeffrey S.; Miller, Ian M.; Johnson, Kirk R.; Honke, Jeffrey S.; Carrara, Paul E.; Muhs, Daniel R.; Skipp, Gary; and Bryant, Bruce, "Geologic setting and stratigraphy of the Ziegler Reservoir fossil site, Snowmass Village, Colorado" (2014). USGS Staff -- Published Research. 936.

https://digitalcommons.unl.edu/usgsstaffpub/936

This Article is brought to you for free and open access by the US Geological Survey at DigitalCommons@University of Nebraska - Lincoln. It has been accepted for inclusion in USGS Staff -- Published Research by an authorized administrator of DigitalCommons@University of Nebraska - Lincoln. 


\section{Authors}

Jeffrey S. Pigati, Ian M. Miller, Kirk R. Johnson, Jeffrey S. Honke, Paul E. Carrara, Daniel R. Muhs, Gary Skipp, and Bruce Bryant 


\title{
Geologic setting and stratigraphy of the Ziegler Reservoir fossil site, Snowmass Village, Colorado
}

\author{
Jeffrey S. Pigati a,* ${ }^{\text {, Ian M. Miller }}{ }^{\text {b }}$, Kirk R. Johnson ${ }^{\text {b,1 }}$, Jeffrey S. Honke a , Paul E. Carrara ${ }^{\text {a }}$, Daniel R. Muhs ${ }^{\text {a }}$, \\ Gary Skipp ${ }^{\text {a }}$, Bruce Bryant ${ }^{\mathrm{a}}$ \\ a U.S. Geological Survey, Denver Federal Center, Box 25046, MS-980, Denver, CO 80225, USA \\ b Department of Earth Sciences, Denver Museum of Nature and Science, Denver, CO 80205, USA
}

\section{A R T I C L E I N F O}

Article history:

Received 30 September 2013

Available online 12 February 2014

\section{Keywords:}

Bull Lake glaciation

Pleistocene fossils

Snowmastodon

Paleoclimate

Stratigraphy

\begin{abstract}
A B S T R A C T
The geologic setting of the Ziegler Reservoir fossil site is somewhat unusual - the sediments containing the Pleistocene fossils were deposited in a lake on top of a ridge. The lake basin was formed near Snowmass Village, Colorado (USA) when a glacier flowing down Snowmass Creek Valley became thick enough to overtop a low point in the eastern valley wall and entered the head of Brush Creek Valley. When the glacier retreated at about 155-130 ka, near the end of Marine Oxygen Isotope Stage 6, the Brush Creek Valley lobe left behind a moraine that impounded a small alpine lake. The lake was initially $\sim 10 \mathrm{~m}$ deep and appears to have been highly productive during most of its existence, based on the abundant and exquisitely preserved organic material present in the sediments. Over time, the basin slowly filled with (mostly) eolian sediment such that by $\sim 87 \mathrm{ka}$ it contained a marsh or wetland rather than a true lake. Open-water conditions returned briefly between $\sim 77$ and 55 ka before the impoundment was finally breached to the east, establishing ties with the Brush Creek drainage system and creating an alpine meadow that persisted until historic times.
\end{abstract}

Published by Elsevier Inc. on behalf of University of Washington.

\section{Introduction}

In 1958, Doug Ziegler and his family purchased a tract of land located just outside Snowmass Village in Pitkin County, Colorado. The tract included a small, gently sloping meadow situated at the divide between Brush Creek and Snowmass Creek at an elevation of $\sim 2705 \mathrm{~m}$ above sea level (Fig. 1). The meadow was the remnant of a small alpine lake that had become filled with sediment, and was used for grazing sheep and similar activities during historic times. Three years later, in 1961, the Ziegler family commissioned the construction of a small earthen dam that blocked the meadow drainage and formed a shallow, private lake initially called Lake Deborah and later Ziegler Reservoir. The manmade lake was similar in size to the natural lake that occupied the site previously, roughly 5 ha, and persisted for nearly five decades before the water rights were sold to the Snowmass Water and Sanitation District in 2010 .

The setting of Ziegler Reservoir is unusual in that the topography surrounding the basin drops off on all sides: toward Brush Creek to the south and east, Snowmass Creek to the west, and an unnamed drainage to the north. Essentially, the lakes (both natural and manmade) sat in a bowl on top of a ridge, devoid of significant surface flow either into or out of the basin. Efforts to expand the reservoir

\footnotetext{
* Corresponding author. Tel.: +1 3032367870 (phone); fax: +1 3032365349 .

E-mail address: jpigati@usgs.gov (J.S. Pigati).

1 Current address: National Museum of Natural History, Smithsonian Institution, 1000 Jefferson Dr SW, Washington, DC 20004, USA.
}

began in September 2010. Shortly thereafter, on the afternoon of October 14,2010 , bulldozer operator Jesse Steele uncovered several rib bones, vertebrae, and part of a tusk of a juvenile Columbian mammoth. The discovery was the first in a series of spectacular finds that ultimately became one of the largest and most prolific Pleistocene fossil sites in North America.

Within days of the discovery, scientists from the Denver Museum of Nature and Science and, later, the U.S. Geological Survey arrived on site. Excavation of thousands of Pleistocene fossils, detailed examination of the site stratigraphy, and sediment sampling were conducted alongside earth-moving equipment as the reservoir expansion project continued. All of the field work, fossil excavations, and sampling efforts were completed at a breakneck pace during two field seasons, spanning just 18 days in the fall of 2010 and 51 days in the summer of 2011. A firsthand account of the discovery and subsequent work at the site is detailed in Johnson and Miller (2012).

This manuscript summarizes the geologic setting, sedimentology, and stratigraphy of the Ziegler Reservoir fossil site (ZRFS). The primary goals of the paper are to give the reader an understanding of how the lake formed, place the site in the larger context of Quaternary geology and climatic cycles in the Rocky Mountains, provide detailed descriptions of the lake-center and near-shore sediments in which the fossils were found, and infer past depositional settings based on the sedimentologic, stratigraphic, and mineralogic properties of the sediments. Although part of a series of papers in a special issue devoted to the site, it is intended to serve as a stand-alone paper with the exception of the site chronology. Specific ages of sediments or units that are referred to 


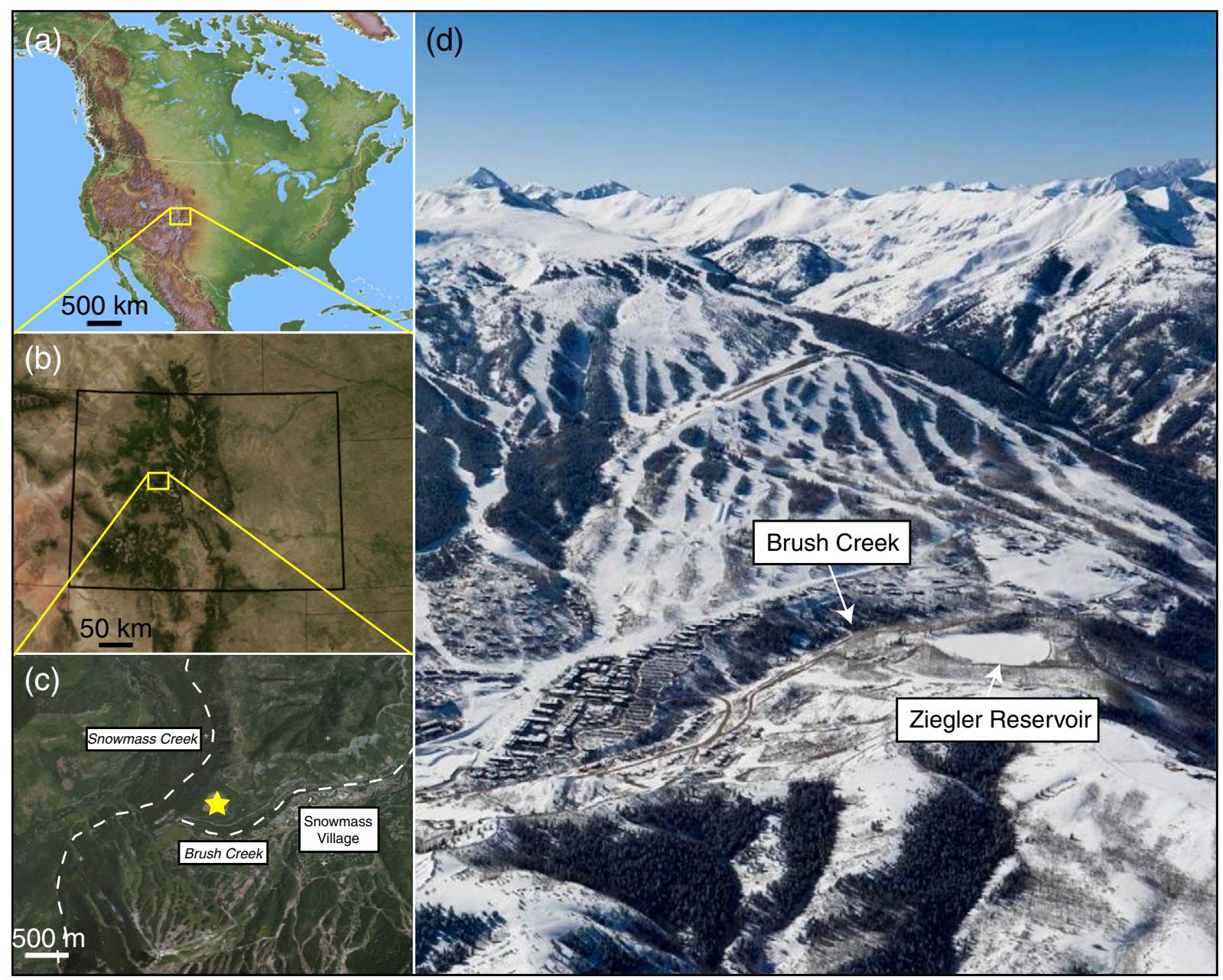

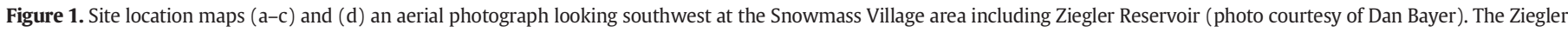
Reservoir fossil site is located at $39.2075^{\circ} \mathrm{N}, 106.9648^{\circ} \mathrm{W}$ and sits at an elevation of $\sim 2705 \mathrm{~m}$.

herein are based on a series of luminescence, radiocarbon, uraniumseries and cosmogenic dates as described in Mahan et al. (2014-in this volume).

\section{Geologic setting}

\section{Bedrock}

The ZRFS is located in the Elk Mountains of west-central Colorado, a high, rugged mountain range that includes several peaks in excess of $4300 \mathrm{~m}$. Trending to the northwest and stretching for more than $\sim 80 \mathrm{~km}$, the Elk Mountains are composed largely of Paleozoic and Cretaceous sedimentary rocks - mostly sandstones, siltstones, mudstones, and shale, as well as Oligocene intrusive rocks that account for many of the range's highest peaks (Tweto, 1979). Although the area around Ziegler Reservoir is tectonically stable today, the Snowmass Creek fault zone is located just west of the site in Snowmass Creek Valley, and is central to local copper and silver mining operations (Bryant, 1979).

Two sedimentary units, the Mancos Shale and Maroon Formation, are particularly important to the geologic setting of the fossil site. The Mancos Shale consists of a thick sequence of dark-gray to black fissile shale and silty shale interbedded with thin lenticular beds, generally less than $25 \mathrm{~cm}$ thick, of fine- to medium-grained olive-gray sandstone and limestone. These strata were deposited in marine environments during the Late Cretaceous and underlie the Quaternary sediments that encompass Ziegler Reservoir. They are also exposed throughout
Brush Creek Valley, including the area just north of the site (Bryant, 1972).

The Maroon Formation is a grayish-red to reddish-brown mixture of calcareous, micaceous, and feldspathic sandstone, siltstone, mudstone, and conglomerate, as well as a few thin beds of limestone, that are collectively Pennsylvanian-Permian in age. Just south of the ZRFS, on the ridge between Willow Creek and East Snowmass Creek, the Maroon Formation is composed of $\sim 300 \mathrm{~m}$ of interbedded siltstone and finegrained sandstone (Bryant, 1979). Reddish-brown clasts of the Maroon Formation are common throughout the Snowmass Creek and Brush Creek valleys, and compose the majority of the glacial deposits in the ZRFS area.

\section{Glacial deposits}

Like other mountain ranges in Colorado, the Elk Mountains were extensively glaciated during the late Pleistocene. The largest glacier in the area occupied the Roaring Fork Valley, $\sim 10 \mathrm{~km}$ east of the ZRFS, and reached a length of about $32 \mathrm{~km}$ during the Bull Lake glaciation (Marine Oxygen Isotope Stage, or MIS, 6) (Bryant and Martin, 1988). Immediately west of the fossil site, Snowmass Creek Valley was occupied multiple times by large glaciers. Headed in cirques high in the Elk Mountains, the largest of the Snowmass Creek glaciers extended nearly $26 \mathrm{~km}$ downslope, was more than $250 \mathrm{~m}$ thick, and terminated at an elevation of $2315 \mathrm{~m}$ (Fig. 2a). As it neared its maximum extent, the Snowmass Creek Valley glacier was thick enough to overtop a low point in a ridge on the eastern wall of the 
valley, $\sim 8 \mathrm{~km}$ upslope from its terminus, and a small lobe of ice flowed into the head of Brush Creek Valley.

When the glacier retreated, the Brush Creek lobe left a small moraine that impounded a $\sim 14.2$ ha drainage basin, forming a small alpine lake that ultimately filled with sediment and became part of the meadow purchased by the Ziegler family. Fortuitously, glaciers that later flowed down Snowmass Creek Valley, most notably during the Pinedale glaciation (or MIS 2), were not large enough to overtop the valley wall and, thus, the lake sediments and fossils were left untouched.

a

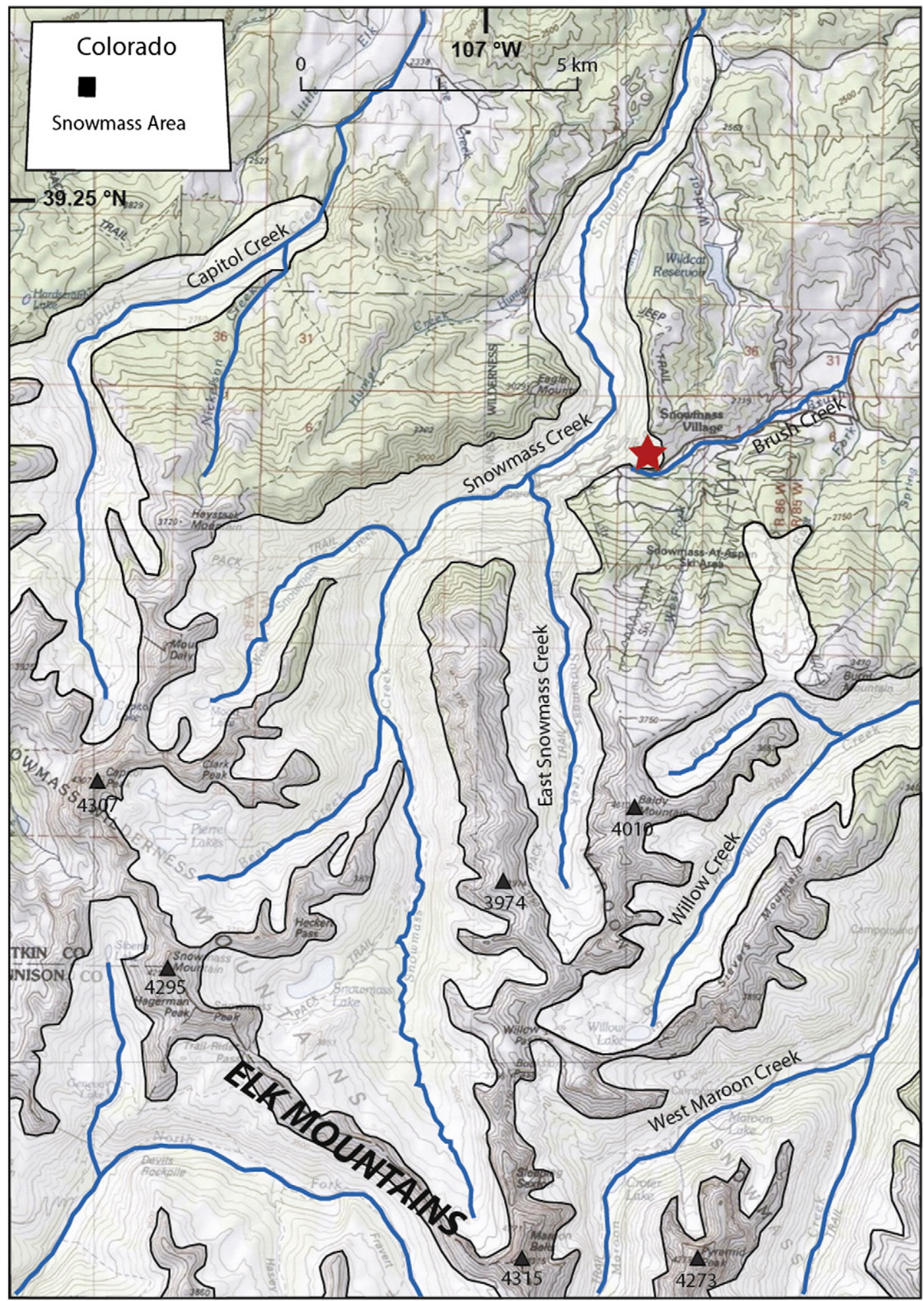

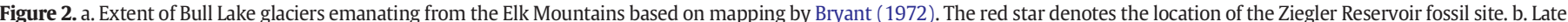

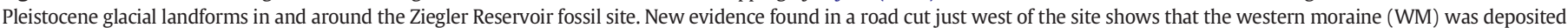

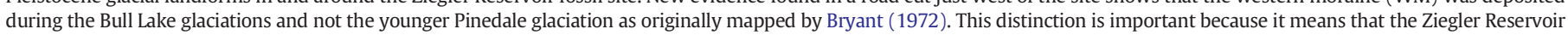
basin was impounded, and likely contained a lake, when the Bull Lake glacier receded from the area at 155-130 ka. 


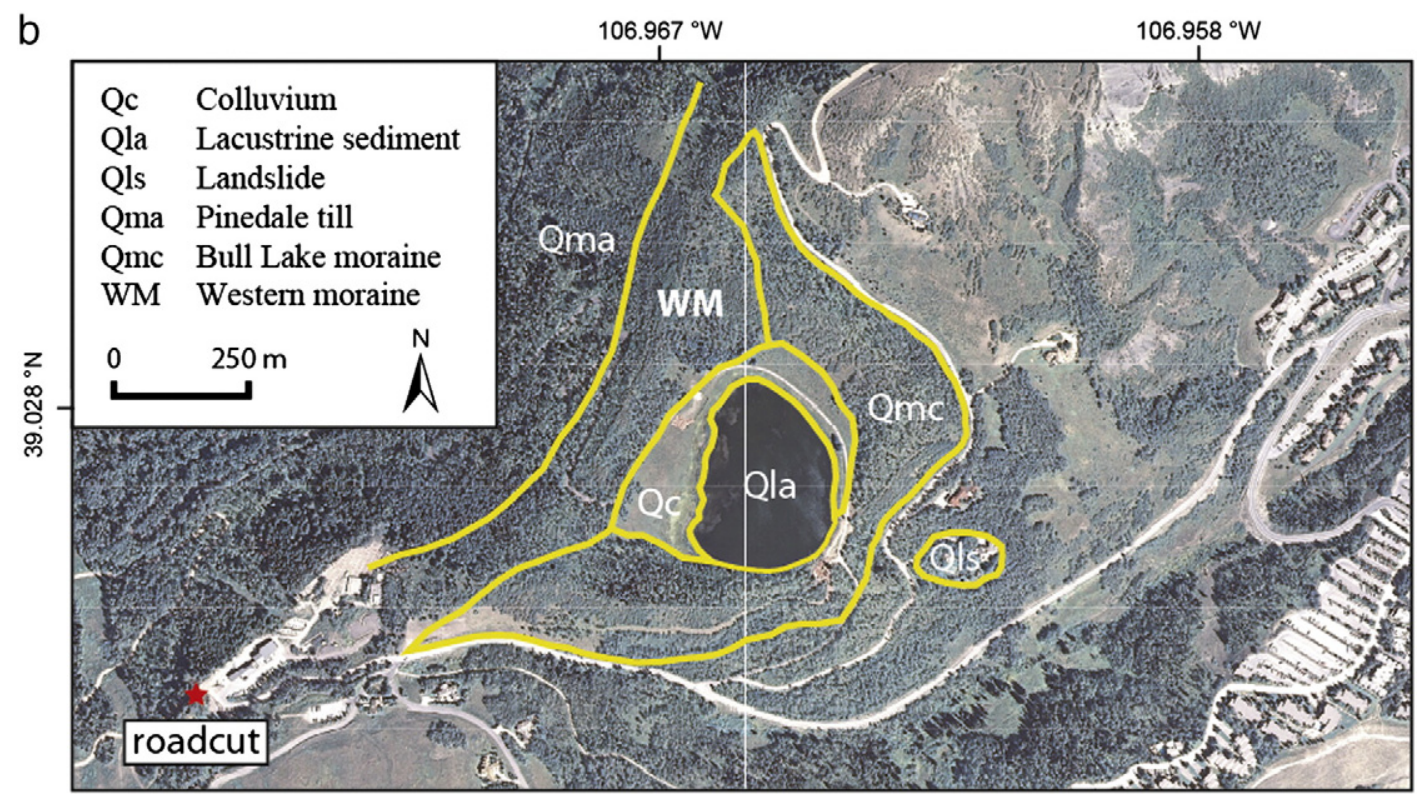

Figure 2 (continued)

The small lobe of glacial till that composes the moraine and underlies the reservoir is as much as $23 \mathrm{~m}$ thick in the vicinity of the earthen dam at Ziegler Reservoir (Knell, 2009), and consists of unstratified, unsorted, matrix- to clast-supported, pebbly cobbles and gravels in a dense, reddish-brown (2.5YR 5/4), clayey sand matrix. The till contains subrounded clasts up to $1 \mathrm{~m}$ in diameter of sandstone and conglomerate from the Maroon Formation, highly weathered granitic pebbles and cobbles, and white to gray clasts of Mancos Shale.

\section{Relative ages of moraines in the ZRFS area}

Critical to the interpretation of the geologic history of the ZRFS is confirmation of the ages of the glacial deposits that hosted the paleolake and blanket the surrounding area. Bryant (1972) mapped the geology of the Highland Peak 7.5' quadrangle, which includes Ziegler Reservoir, and recognized four relative ages of tills, in order from oldest to youngest, Qmd, Qmc, Qmb, and Qma. Although initially Bryant did not correlate his till units with the Rocky Mountain glacial stratigraphy of the time, he later correlated his unit Qmd with the Sacagawea Ridge glaciation, unit Qmc with the Bull Lake glaciation, and the younger units ( $\mathrm{mb}$ and Qma) with the Pinedale glaciation (Bryant, 1979). The ZRFS is situated within deposits that were designated as unit Qmc.

New age determinations of the past decade shed some light on the ages of glacial deposits in the Rocky Mountains, although the Sacagawea Ridge glaciation is still not directly dated. Based on cosmogenic surface exposure ages from localities in the Yellowstone region and Teton Mountains of Wyoming, the Bull Lake glaciation is now thought to date to approximately $155-130 \mathrm{ka}$, which corresponds to the latter part of MIS 6 (Licciardi and Pierce, 2008). In the Yellowstone region, again based on cosmogenic age determinations, Pinedale moraines reached their maximum extents during MIS 2 between $~ 19$ and $16 \mathrm{ka}$ (Licciardi and Pierce, 2008). In Colorado, there is less certainty about the ages of Bull Lake glacial deposits (Benson et al., 2004), but Pinedale deposits are dated within the same general age range as those in Wyoming, albeit with some regional variance (Benson et al., 2005; Ward et al., 2009; Young et al., 2011).

Given this background, one of our goals was to test Bryant's (1979) correlations of the ZRFS glacial deposits to the Rocky Mountain glacial stratigraphy. We agree that the Qmd deposits are the oldest glacial sediments in the nearby drainage basins, based on height above the younger moraines and cross-cutting relations. However, rather than correlate the Qmd till with the Sacagawea Ridge glaciation, we refer to these deposits as simply of pre-Bull Lake age. Bull Lake moraines (Qmc) have more rounded crests and are older than the Qmb and Qma deposits based on cross-cutting relations. In the ZRFS area, surface boulders on the Qmc moraines are extremely rare whereas Qmb and Qma moraines have abundant on the moraine surface and sharper crests (Fig. 3). Based on our field observations, and apart from a slight westward shift of the contact between the Qma and Qmc units in the area immediately west of Ziegler Reservoir, we agree with the mapping of the ZRFS deposits by Bryant (1972) and the correlations of Bryant (1979) of the Qmd deposits to a pre-Bull Lake glaciation, Qmc deposits to the Bull Lake glaciation, and Qmb and Qma deposits to the Pinedale glaciation.

Our interpretations of the ages of moraines in Snowmass Creek Valley are supported by the degree of soil development present in the local tills. Using soil development to assess ages of Quaternary tills has a long tradition in the Rocky Mountains (see Birkeland, 1999, and Birkeland et al., 2003, for reviews). In the Front Range of Colorado, Birkeland et al. (2003) observed that Bull Lake tills that developed under forest cover typically have $\mathrm{O} / \mathrm{E} / \mathrm{Bt} / \mathrm{C}$ or $\mathrm{A} / \mathrm{E} / \mathrm{Bt} / \mathrm{C}$ profiles, with $7.5 \mathrm{YR}$ hues in the Bt horizon, up to $16 \%$ clay content in the Bt horizon, and $20 \%$ of crystalline rocks weathered to grus. In the same region, soils in Pinedale tills that developed under forest typically have $\mathrm{O} / \mathrm{E} / \mathrm{Bw} / \mathrm{C}$ or $\mathrm{A} / \mathrm{E} / \mathrm{Bw} / \mathrm{C}$ profiles (some have minimally developed Bt horizons), 10YR hues in the Bw horizon, $\sim 10 \%$ clay in the Bw horizon, and with most crystalline clasts unweathered.

In the area mapped as Qmc (Bull Lake till) by Bryant (1972), we examined soils in two hand-dug pits on the moraine crest developed under a mature aspen-fir forest (Fig. 4). Both pedons on this moraine are at least $100 \mathrm{~cm}$ thick, with $\mathrm{A} / \mathrm{E} / \mathrm{Bw} / \mathrm{Bt} / \mathrm{B} / \mathrm{C}$ profiles. The $\mathrm{A}$ horizons have very dark brown, or grayish-brown (10YR 4/2,3/2, 2/2) dry colors with silt loam textures and weak-to-moderate, fine-to-coarse granular structure. The E horizons have grayish-brown, light grayish-brown (10YR $5 / 2,6 / 2$ ) or reddish-brown (5YR 5/3) dry colors, silt loam or light silty clay loam textures, and weak-to-strong, very fine-tomedium subangular blocky structure. Both soil profiles have wellexpressed B horizons. The pedon at soil pit \#1 displays a B horizon that is at least $50 \mathrm{~cm}$ thick, with light reddish-brown to yellowish-red (5YR $6 / 4,4 / 6)$ to red $(2.5 Y R 4 / 6,10 \mathrm{R} 4 / 6,5 / 6)$ dry colors, loamy to light silty clay loam textures, and weak-to-moderate, fine-to-coarse 

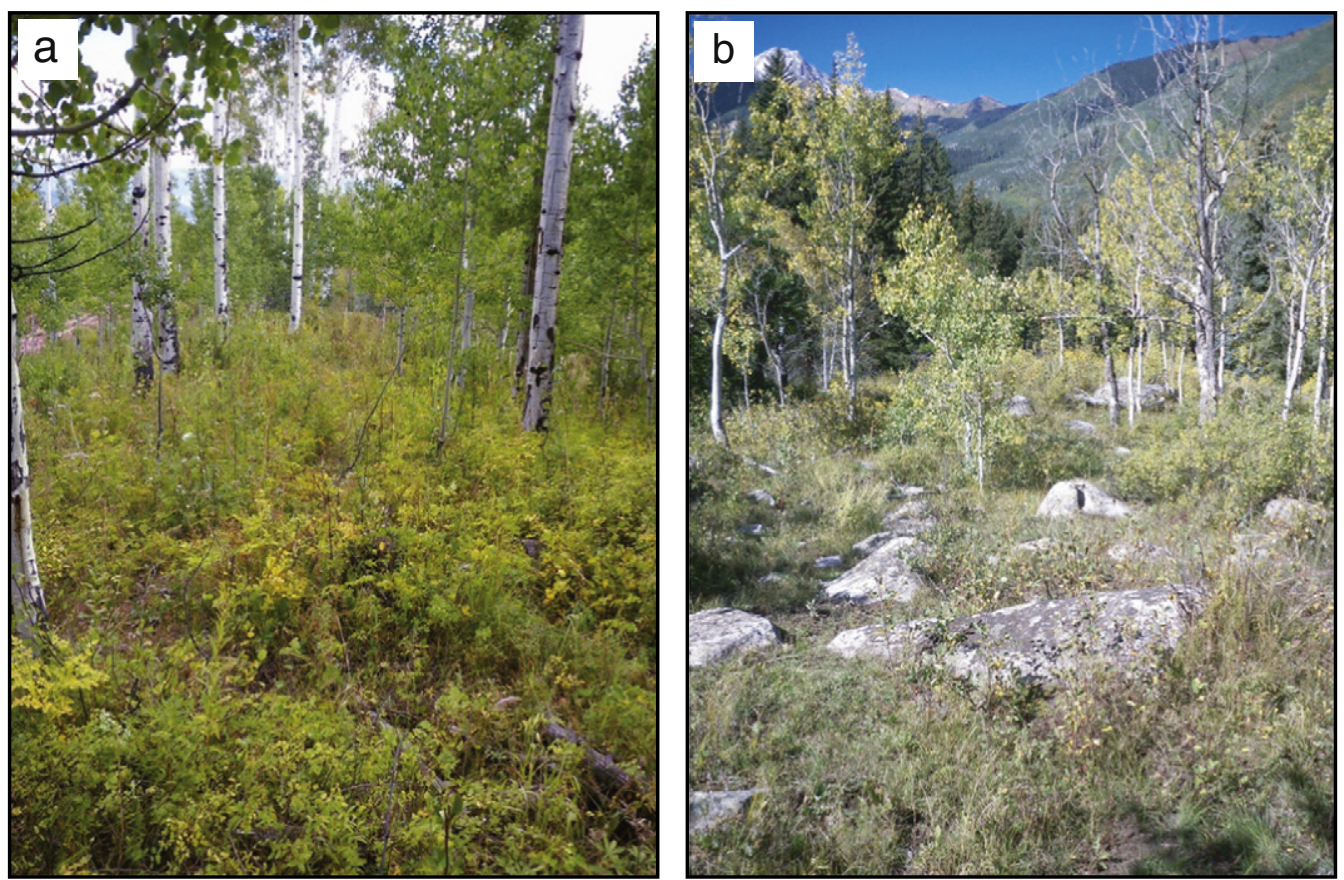

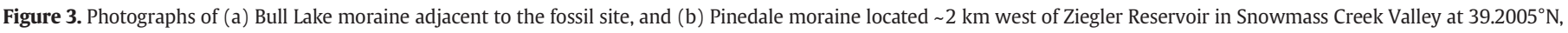

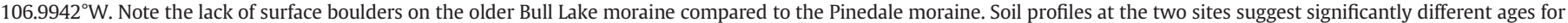
the host moraines.

subangular blocky structure. Similarly, the pedon at soil pit \#2 displays a $\mathrm{B}$ horizon that is at least $56 \mathrm{~cm}$ thick (we did not reach the $\mathrm{C}$ horizon in this pit) with reddish-brown (2.5YR 5/4) dry colors, sandy loam to silty clay loam textures, and structureless or fine-to-medium, moderate subangular blocky structure.
Soils on the Pinedale (Qma) moraines in the Snowmass Creek Valley are not as well developed as either of the pedons on the Bull Lake (Qmc) moraines, typically having $\mathrm{A} / \mathrm{E} / \mathrm{Bw} / \mathrm{C}$ profiles. The $\mathrm{A}$ horizons have very dark brown to very dark grayish-brown (10YR 2/1, 2/2, 3/2) dry colors, silt loam textures, and weak-to-strong, very fine-to-coarse granular

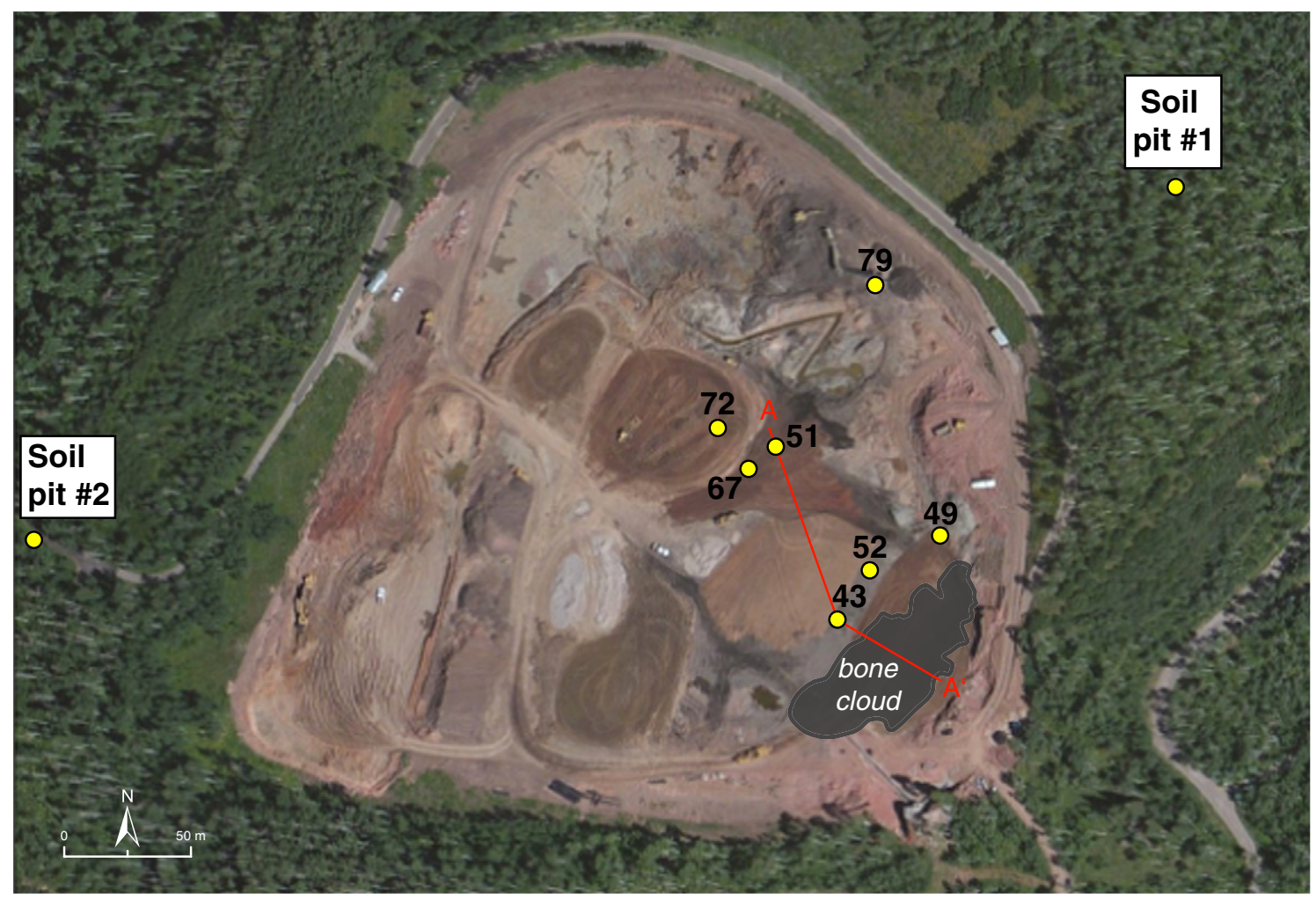

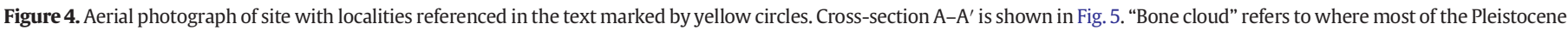
fossils were found and corresponds to the deepest part of the paleolake. 
structures. The E horizons have grayish-brown (10YR 5/2, 4/2) light gray (10YR $7 / 2$ ), or light brownish gray (10YR 6/2) dry colors, silt loam textures, and strong, fine-to-medium, granular-to-subangularblocky structure. All B horizons have yellowish-brown (10YR 4/4,5/4) or brown (10YR $5 / 3$ or 7.5 YR $5 / 3$ ) dry colors, loamy textures, and weak-to-strong, fine-to-medium subangular blocky structures.

Direct comparison of our soil data to the Bull Lake/Pinedale soil criteria outlined by Birkeland et al. (2003) is difficult because unlike the crystalline rock compositions (granites and metamorphic rocks) that dominate the Front Range, tills here also contain fine-grained clasts of Mancos Shale and reddish-brown sandstone clasts of the Maroon Formation. Nevertheless, we find both similarities and differences between the soils on the Bull Lake and Pinedale moraines. In soils on both the Bull Lake and Pinedale moraines, we interpret the A and E horizon textures of silt loam and light silty clay loam to indicate possible additions of eolian silt and/or clay to the tops of the profiles, which has been documented elsewhere for soils on glacial deposits in Colorado (Muhs and Benedict, 2006). In the soils on the Bull Lake moraines, the relatively clay-rich B horizons with subangular blocky structure are consistent with the well-developed B horizons found in soils on Bull Lake tills in the Colorado Front Range (Birkeland et al., 2003). We note that the B horizon hues (10R, 2.5YR, and 5YR) of Bull Lake soils near Snowmass are much redder than hues (7.5YR) that are typical of Bull Lake soil B horizons in the Colorado Front Range. However, we attribute the redder colors of soils near Snowmass to be inherited, at least in part, from the reddish-brown colors found in clasts of the Maroon Formation.

In contrast, B horizons of soils in the Pinedale tills are not as well developed as those in the Bull Lake tills. Clay content is much lower, based on field estimates of textures, and hues (10YR and 7.5YR) are not as red as those in the B horizons of the soils in the Bull Lake tills (10R, 2.5YR, 5YR). Although some of the dramatic redness seen in the $B$ horizons of soils on the Bull Lake moraine are probably the result of weathering of clasts from the Maroon Formation, development of these colors seems to be largely a time-dependent process. Soils in tills of the Pinedale moraines have B horizons that lack red colors, despite the fact that these tills also contain clasts from the Maroon Formation.

In sum, on the basis of cross-cutting relations, moraine morphology, frequency of surface boulders, and B horizon colors and textures, we agree with Bryant (1979) that the Qmc moraines that contain the ZRFS were deposited during the Bull Lake glaciation (late MIS 6). These same criteria support Bryant's interpretation that the Qma moraines likely correlate with the Pinedale glaciation (MIS 2). It is possible that the Qmb moraines correlate with an "early Pinedale" glaciation, perhaps representing an ice advance that occurred during MIS 4, but evidence for such a glacial advance has not been well documented in most of the Rocky Mountain region and is beyond the scope of this project.

The one area where we differ from Bryant's mapping is the relative age of the moraine that impounds the western portion of the Ziegler Reservoir basin. This area was originally mapped by Bryant (1972) as Qma (designated as unit WM on Fig. 2b), which would suggest that the basin may not have been impounded entirely until approximately the last glacial maximum (LGM). However, based on a glacial sedimentary sequence that we observed in a nearby road cut $\left(39.20504^{\circ} \mathrm{N}\right.$; 106.97336 ${ }^{\circ} \mathrm{W}$, elevation $2729 \mathrm{~m}$; Fig. 2b) that occurs within Bryant's Qma, the boundary between Bull Lake (Qmc) and Pinedale (Qma) deposits should be moved slightly west of its original location. At this road cut, $\sim 2-3 \mathrm{~m}$ of colluvium overlie a till that has (in places) an $\mathrm{A} / \mathrm{E} /$ $\mathrm{Bt} / \mathrm{C}$ profile, with abundant, highly weathered granite clasts in the subsurface. This degree of soil development and the weathered clasts in the subsurface closely resembles characteristics we found elsewhere on the Qmc moraines, and not Qma. This shift is important because it implies that the impounding moraine on the northwest part of the basin was present during Bull Lake times and, therefore, the lake was fully impounded when the Bull Lake glacier receded from the area.

\section{Site stratigraphy}

The ZRFS is contained within the bounds of the former reservoir, an essentially circular feature that is $\sim 300 \mathrm{~m}$ in diameter (Fig. 4). Most of the vertebrate fossils were concentrated in the southeast quadrant of the site in an area known as the "bone cloud," which was also the deepest part of the paleolake. When the Snowmass Creek Valley glacier first receded at the end of MIS 6, the lake was probably 10 m deep in this area and shallowed to the west based on previous depth to till measurements (Knell, 2009).

When scientists arrived in October 2010, large portions of the lake sediment in the southeast quadrant of the site had already been removed as part of the reservoir enlargement project. In addition, much of the western part of the site was covered by fill material to be used to line the bottom of the enlarged reservoir, further limiting access to the site stratigraphy. Lake sediments were clearly exposed, however, in a 4-m high, man-made outcrop at Locality 43 , and in trenches at localities 49, 51, and 52. In addition, five sediment cores (A-E) were drilled down to glacial till using a Giddings Soil Probe ${ }^{2}$ in an area adjacent to Locality 43 , and revealed several units that were not exposed in either the trenches or outcrop. Two additional sediment cores were taken for archiving purposes at localities 72 and 79.

Sediments exposed on opposite sides of the excavated area southeast of localities 43 and 52 were quite different in terms of grain size, sorting, and origin (Fig. 5). Sediments in the interior part of the basin were well-sorted and fine-grained, and units could be traced laterally across the site. In contrast, alternating strata consisting of well-sorted, fine-grained sediments and poorly sorted, coarse-grained colluvium were exposed along the eastern edge of the basin. The fine-grained sediments extended into the interior of the basin, but the coarser units generally pinched out within $\sim 50 \mathrm{~m}$ of the basin margin. Only Unit 10 (also known as the "Yellow Brick Road") was found on both sides of the excavation. Poorly sorted sand and gravel in Unit 7 of Core A appear to correlate with the coarse-grained Main Floor unit farther to the east, providing a second tie point between the lake-center and near-shore sediments. Additionally, at Locality 49, Unit 8 sits directly on top of the Primary Debris Flow, providing a third set of tie points between the lake-margin and lake-center sediments (Fig. 5). Detailed descriptions of the sediments, as well as a discussion of their origin and modes of deposition, are presented in the following sections.

\section{Lake-center sediments}

A total of 18 units were identified in the interior portion of the lake, including 16 fine-grained units that together are $\sim 10 \mathrm{~m}$ thick, glacial till (Unit 2), and the underlying Mancos Shale (Unit 1) (Fig. 6). Unit thickness of the fine-grained sediments ranged from $\sim 12 \mathrm{~cm}$ (Unit 12) to $\sim 1.5 \mathrm{~m}$ (Unit 18), with clear to abrupt contacts between each unit (Fig. 7).

\section{Particle size analysis}

Lake-center sediments were analyzed for particle size using the standard pipette method at the University of Iowa's Quaternary Materials Laboratory. The presence of mica in the sediments precluded the use of automated optical systems because grains could be counted as clay, for example, if they were oriented in one direction and silt if oriented in another. A total of 24 samples were analyzed, representing units exposed in outcrop at localities 43 and 51, as well as in Core A. Silt constitutes the bulk of the lake-center sediments (43-86\%) with lesser contributions from clay (9-45\%) and sand (1-33\%) (Fig. 8). Silt was most abundant near the middle of the profile in units $10-14$, where it accounted for more than $80 \%$ of the total, and concentrations never fell below $\sim 40 \%$ in any of the other units. Concentrations of clay-sized

\footnotetext{
${ }^{2}$ Any use of trade, product, or firm names is for descriptive purposes only and does not imply endorsement by the U.S. Government.
} 


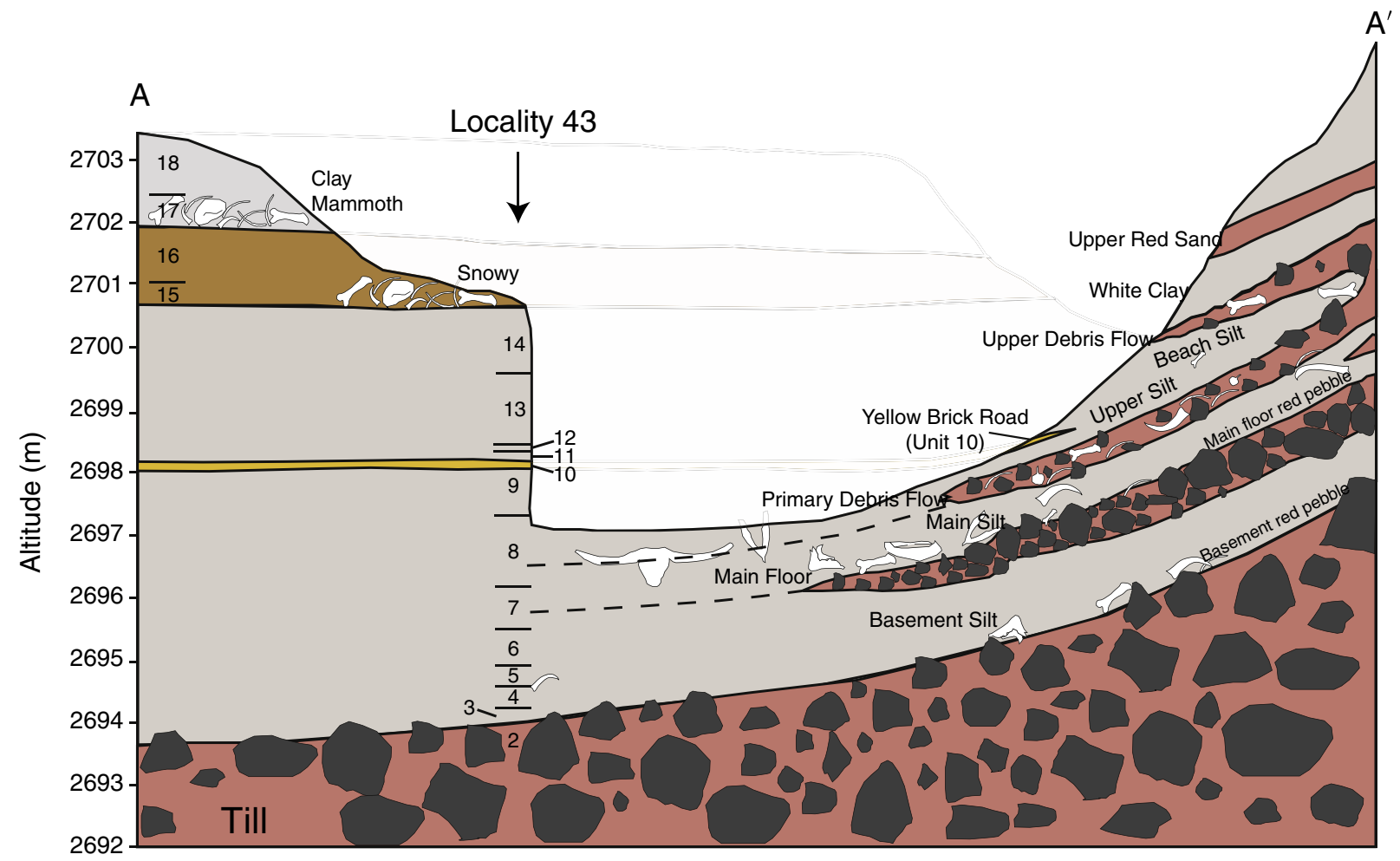

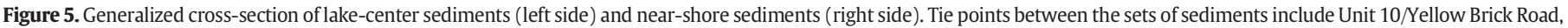

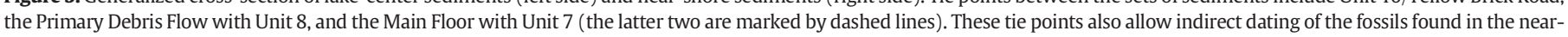
shore sediments via luminescence ages obtained from Locality 43 (Mahan et al., 2014-in this volume).

particles were highest near the base (units 3-4) and top (units 15-18) of the profile, reaching $30-40 \%$ at both depth intervals, but were only $10 \%$ or lower in the middle units. Sand was abundant only lower in the profile, peaking in Unit 7 where the Main Floor unit extended into the center of the lake basin. We note that Main Floor sediments were not present in all of the cores, which were drilled very close to one another near Locality 43 , suggesting that the core locations essentially marked the distal limit of this unit. Relatively high concentrations of sand were also present in Unit 8 of Core A, but we cannot trace its origin back to the near-shore sediments. Sand only accounts for a few percent of the total for the remainder of the sediments analyzed.

\section{Mineralogy}

We used X-ray diffraction (XRD) techniques to determine the relative abundances of common minerals and clays in the very fine sand $(125$ to $53 \mu \mathrm{m} ; \mathrm{n}=6$ ), silt ( 53 to $2 \mu \mathrm{m} ; \mathrm{n}=23$ ), and clay $(<2 \mu \mathrm{m} ; \mathrm{n}=23$ ) fractions of samples representing all 16 fine-grained units. Quartz accounted for $78-90 \%$ of the very fine sand fraction, feldspars ranged from 6 to $19 \%$, and micas accounted for only a few percent of the total. Similarly, quartz dominated the silt fraction, ranging from 66 to 93\% of the total. Feldspars again were the next largest component, ranging from 5 to $31 \%$, and micas accounted for $0-4 \%$ of the total. Chlorite was also present in small amounts within the silt fraction in all units except units 7 and 8 , with concentrations ranging up to $2 \%$.

A semi-quantitative analysis of the clay mineralogy was performed on 23 samples from the sediment profile based on the Glass method developed at the Illinois State Geological Survey and later modified by Hallberg et al. (1978). This method is based on the difference between the counts per second (CPS) data on the X-ray diffractogram and a logarithmic baseline curve. The CPS data of a glycolated aliquot of the sediment were taken from the expandable clay (smectite) peak $\left(5.2^{\circ}, 2 \theta\right.$, $17 \AA$ ), the mica/illite peak $\left(8.8^{\circ}, 2 \theta, 10 \AA\right)$, and the kaolinite-pluschlorite peak $\left(12.4^{\circ}, 2 \theta, 7.1 \AA\right)$. The results of the Glass analysis show that kaolinite concentrations remain fairly uniform throughout the profile, accounting for $28-36 \%$ of the total clay content, whereas smectites increase gradually from bottom to top, ranging from $12 \%$ in Unit 3 to a peak value of $36 \%$ in Unit 18 . In contrast, illite decreases gradually from bottom to top, from 52\% in Unit 3 to $35 \%$ in Unit 18.

Finally, we measured the carbonate concentrations of the lakecenter sediments, including individual percentages of calcite and dolomite, using a Chittick gasometric device. Results show that calcite concentrations ranged up to $29 \%$, and were highest in units 13 and 14 (Fig. 8). Dolomite concentrations were far lower, never exceeding more than 6\%, and reaching maximum levels in Unit 10.

\section{Origin of lake-center sediments}

One of our primary research questions relates to the origin of the lake-center sediments. Presumably there has been little surface input of clastic material into the lake considering the small catchment area, a lack of recognizable surface drainages leading into the basin, and the absence of fluvial or alluvial sedimentary structures in the lake sediments themselves. Results of the particle size analysis suggest that eolian processes may be, at least in part, responsible for transport and deposition of sediments into the lake basin. The grain size of samples taken at units 10-14, as well as Unit 5, are nearly identical to loess standards used by the University of Iowa's Quaternary Materials Laboratory, and samples from units 7 and 8 (excluding the sand and gravels derived from the Main Floor) exhibited a particle size distribution similar to modern dust collected near the ZRFS in 2012 (Fig. 9). The lake-center sediments are also similar to loess mantles found on rock glacier deposits near Mt. Sopris to the north (Birkeland, 1973) and fine-grained, loess-like sediments that accumulated in structural depressions in the Aspen Highlands Ski Area to the southeast (McCalpin and Irvine, 1995). In addition, luminescence signals for most of the lake-center sediment samples collected for dating purposes exhibited consistent and homogeneous properties, which further indicate an eolian, rather than 
Depth

(m)

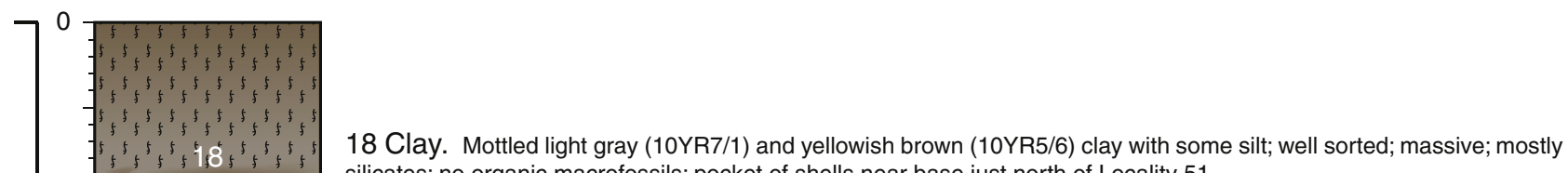

silicates; no organic macrofossils; pocket of shells near base just north of Locality 51

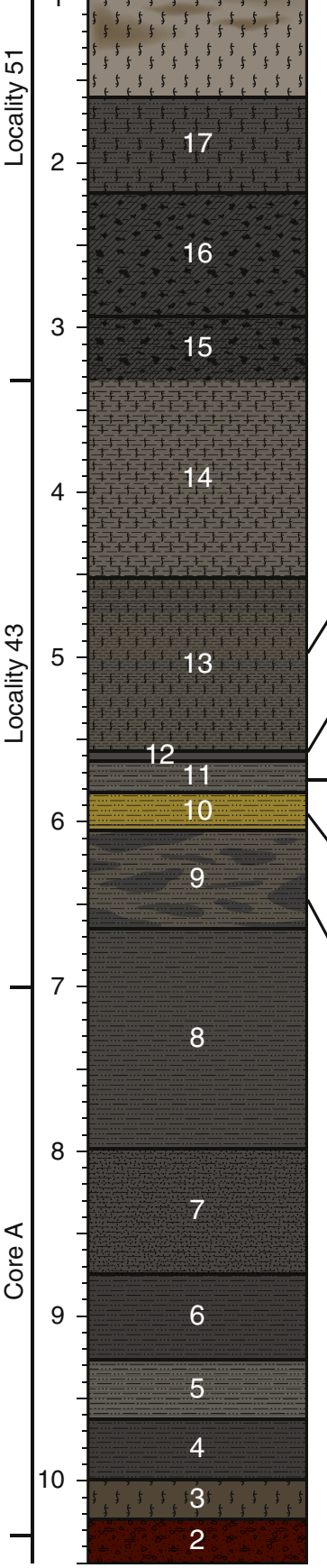

17 Clayey silt. Very dark grayish brown (10YR3/2) clayey silt; well sorted; massive; mostly silicates; weak blocky ped structure

16 Peat. Very dark brown (10YR2/2) peat; massive; no bedding, layering, or color changes; little mineral matter

15 Peaty silt. Black (10YR2/1) silt mixed with peat; platy texture due to bedded vegetation; mostly silicates

14 Massive silty clay. Grayish brown (10YR5/2) silty clay; well sorted; massive with a few very faint darker beds; mostly silicates

13 Bedded silty clay. Dark yellowish brown (10YR4/4) and very dark grayish brown (10YR3/2) bedded silty clay; color beds ranging from $\mathrm{mm}$ to $\mathrm{cm}$ scale; no textural difference across color beds; mostly silicates with rare organics

12 Organic mat. Very dark gray (10YR3/1) silt with abundant organics that include sedge leaves, peaty sediment, and wood; sedge leaves are still greenish in color when first exposed to air but quickly oxidize to orange-brown

-11 Weakly bedded silt. Brown (10YR4/3) silt with faint gray (10YR5/1) beds; well sorted; massive; mostly silicates with a few plant macrofossils and pieces of wood

10 Yellow bedded silt. Yellowish-brown (10YR5/4) silt; well sorted; massive except for a 2-cm thick very dark grayish brown (10YR3/2) bed of organic-rich silt in the lower third of unit; abundant fibrous organic materials, seeds, twigs, and wood; mostly silicates

9 Mottled silt. Mottled brown (10YR4/3) and black (10YR2/1) silt; more clay than unit below; traces of fine sand moderately well sorted; mostly silicates; unit grades into laminated (9a) and massive (9b) subunits to the north

8 Organic-rich silt. Black (2.5Y2.5/1) to very dark gray (2.5Y3/1) silt with small amounts of clay; fine sand lenses present in upper part; massive with faint bedding in places; mostly silicates with some vivianite and micas; slightly more fine grained in lower portion

7 Sandy silt. Very dark grayish brown (2.5Y3/2) silt and fine-medium sand; moderately to poorly sorted; massive with a few small $(\mathrm{mm})$ lenses of carbonate; mostly silts with coarse micas and sands; some sub-rounded quartz grains

6 Organic-rich silt. Similar to Unit 8; black (2.5Y2.5/1) to very dark gray (2.5Y3/1) silt; well sorted; massive; mostly silicates with some micas; abundant organics; slightly finer grained toward base

5 Laminated silty clay. Very dark gray $(2.5 Y 3 / 1)$ to black (10YR2/1) silty clay; well sorted; millimeter laminations alternating between dark and light colors of non-uniform thicknesses; mostly silicates with some micas

4 Organic-rich silt. Black $(2.5 \mathrm{Y} 2.5 / 1)$ to very dark gray $(2.5 \mathrm{Y} 3 / 1)$ silt with some clay; well sorted; massive; occasional fine sand lenses; carbonates lens near base

3 Sticky clay. Dark brown (7.5YR3/2) clay with fine silt; well sorted; massive; faint color bedding; mostly silicates.

2 Till. Diamicton composed mostly of Maroon Formation with some siltstones, shales, and granitic rocks.

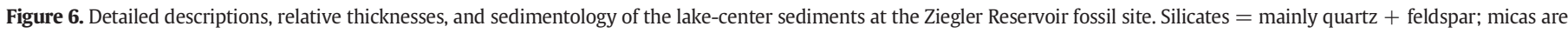
mentioned separately. Organics = carbonaceous material, leaves, twigs, branches, logs, and peat.

fluvial or alluvial, transport mechanism (Mahan et al., 2014-in this volume). Thus, we suggest that at least some, and potentially a large percentage, of the lake-center sediments transported into the basin via eolian processes, although the specific amount, distance, and direction of transport are unknown at this time.

\section{Inferred depositional settings}

With the exception of units 15 and 16, and possibly Unit 12, it appears that all of the lake-center units were deposited in a fully lacustrine setting, rather than a marsh or wetland. We did not observe evidence in the sedimentary record that would indicate the lake dried out 


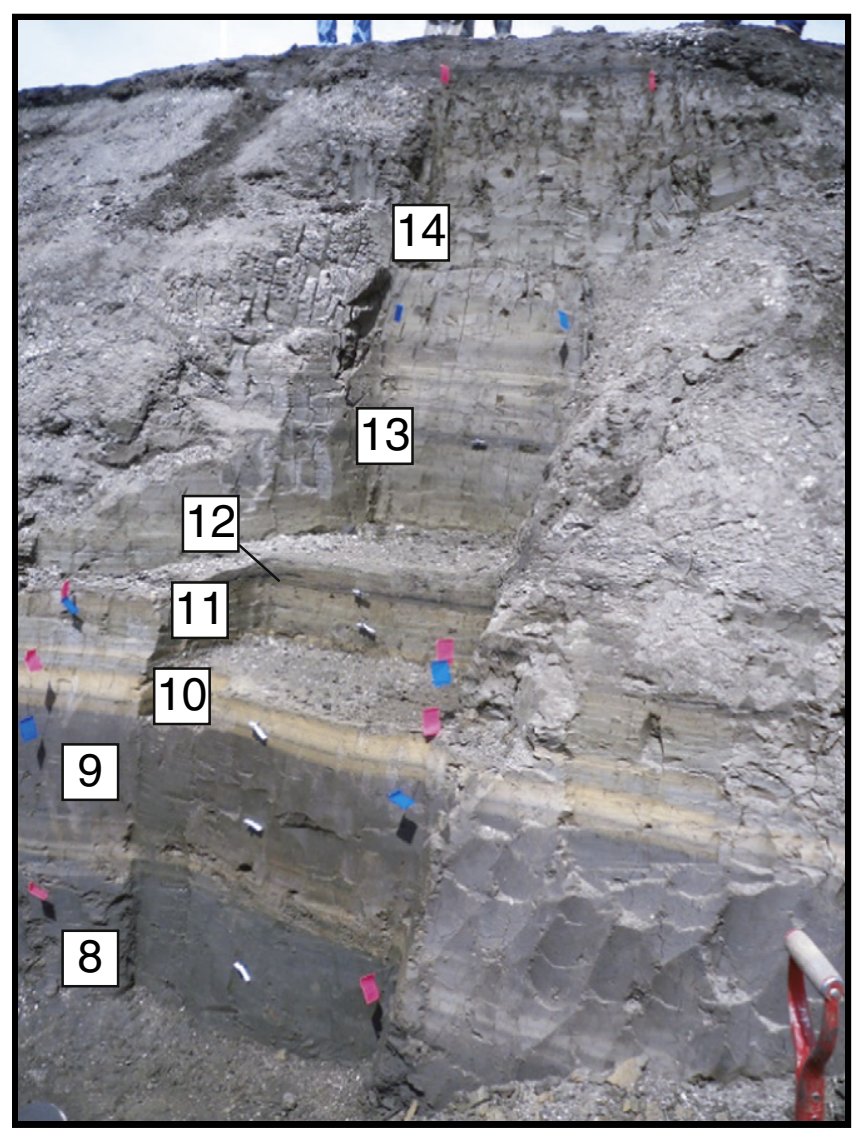

Figure 7. Photograph of a $\sim 4 \mathrm{~m}$ section of lake-center sediments (units 8-14) exposed in outcrop at Locality 43 . The colored flags are on pins that are positioned at unit contacts (paired pink and blue flags are at the same stratigraphic levels).

completely at any time during its existence, although it was probably quite small at various times. We are not able to place specific limits on absolute lake levels through time, but the particle size and mineralogical data presented above offer insight into relative lake levels and depositional settings for the lake-center units. We note that this analysis is independent of other proxy methods used to reconstruct environmental conditions at the ZRFS.

Unit 3 is positioned immediately above the till and contains abundant clay-sized particles, which likely were derived from glacial flour that would have been present in abundance on and within the surrounding moraine as well as in Snowmass Creek Valley at the end of the Bull Lake glaciation. Unit 4 also contains abundant clay, as well as increased organic matter compared to Unit 3, which may reflect the transition of the lake from a barren, kettle-like setting to one with increased organic productivity as temperatures began to warm during MIS 5 e. Above this, units 5 and 6 are dominated by silt, in particular mediumsized silt (16-8 $\mu \mathrm{m})$, which could potentially signal the arrival of relatively far-traveled sediments to the basin. By analogy with the particle size distributions of Asian loess, sediments of this size range are interpreted to have been transported in high suspension over relatively great distances (Vandenberghe, 2013). A mode in the 16-8 $\mu \mathrm{m}$ range is finer grained than eastern Colorado loess that has been transported more than $\sim 100 \mathrm{~km}$ from its source and is also finer grained than alpine soils in the Colorado Front Range that are interpreted to have a regional eolian origin (Muhs and Benedict, 2006). Unit 5 also contains distinct laminations and fine bedding structures, which indicate that quiet water, and possibly a deep lake, likely prevailed at this time. In contrast, Unit 6 is massive and contains abundant organic matter, which suggests relatively low to moderate lake levels and the presence of abundant vegetation.
Unit 7 is similar to the units below in that it consists largely of silt, but the presence of sand and gravels in the upper part of the section reflects input from near-shore sediments. The presence of coarse material in the middle of the basin may indicate a relatively wet climate or at least a series of significant storm events may have occurred at this time, which would have increased the likelihood of debris flows, slumps, and/or coarser sheetwash reaching the middle of the basin. Units 8 and 9 are both composed of organic-rich silt, which suggests a highly productive lake but with less influence from the coarser, nearshore sediments. Unit 9 grades laterally into two distinct subunits, referred to as units 9a (older; laminated) and 9b (younger; massive). Both subunits were exposed at Locality 52 but pinch out locally to the east; neither were present at Locality 49 (Fig. 5).

The mineralogy and grain size distribution of units 10-12 are similar to one another, but the distinct yellowish-brown coloration of Unit 10 suggests a higher oxidation state of iron-bearing minerals in this unit compared to those above and below. This may reflect a shallowing of the lake during its deposition, although we did not observe any changes in either mineralogy or texture between Unit 10 and the adjacent units. Unit 12 contained abundant sedge leaves and other types of vegetation (which were still green when first exposed!), indicating that lake levels were likely low and the basin was heavily vegetated during deposition of this unit. The particle size distribution of the overlying sediments in units 13-14 are similar to units 10-12, as well as loess standards and nearby loess deposits, which again suggests eolian processes delivered the sediments to the basin. However, units 13 and 14 were likely deposited in a deeper lake than the units below as they contained very little organic matter. This interpretation is supported by the presence of faint bedding structures in Unit 13, which would not have been preserved if the lake was shallow and heavily vegetated.

Units 15 and 16 are texturally and compositionally different from the rest of the lake-center sediments. Both contain abundant concentrations of peat and peaty material, which suggests that a shallow marsh or bog was present during their formation, as lake levels either fell and/or the lake became filled in with sediment. In fact, Unit 15 graded laterally into a "root mat" near the basin margin at Locality 49, where it was composed of fine, heavily tangled roots containing little to no sediment.

Lake levels rebounded somewhat during deposition of units 17 and 18 as both units appear to have been deposited in standing water based on the absence of root voids and other evidence of substantive vegetation. Lake levels were likely no more than a few meters high at this time as the basin had become largely filled with sediment. Relatively high clay concentrations, particularly in Unit 18, likely reflect the increased availability of glacial flour in the nearby valleys during MIS 4. Open-lake conditions remained until $\sim 55 \mathrm{ka}$ when the impoundment was finally breached to the east, establishing ties with the Brush Creek drainage system and creating an alpine meadow in the former lake basin.

\section{Near-shore sediments}

In contrast to the sediments present in the middle of the basin, the near-shore sediments are composed of a complex sequence of colluvial, diamictite units interfingered with fine-grained lacustrine sediments (Fig. 10). The coarse-grained diamictite units rarely extend more than $\sim 50 \mathrm{~m}$ from the inner slopes of the moraine toward the basin center before pinching out. Along the strike of the near-shore sediments, there are marked changes in bed thickness, grain size, sorting, and dip. Additionally, the upper and lower contacts of many of the beds exhibit considerable topography. From oldest to youngest, the diamicton units are named Basement Red Pebble, Main Floor, Primary Debris Flow, Upper Debris Flow, and Upper Red Sand (Fig. 5). Two of these names, Primary Debris Flow and Upper Debris Flow, imply genesis but should be taken as names only. (We note that while this is not standard practice, we have elected not to change them as they are tied to the field notes of numerous scientists, as well as hundreds of sediment samples and 


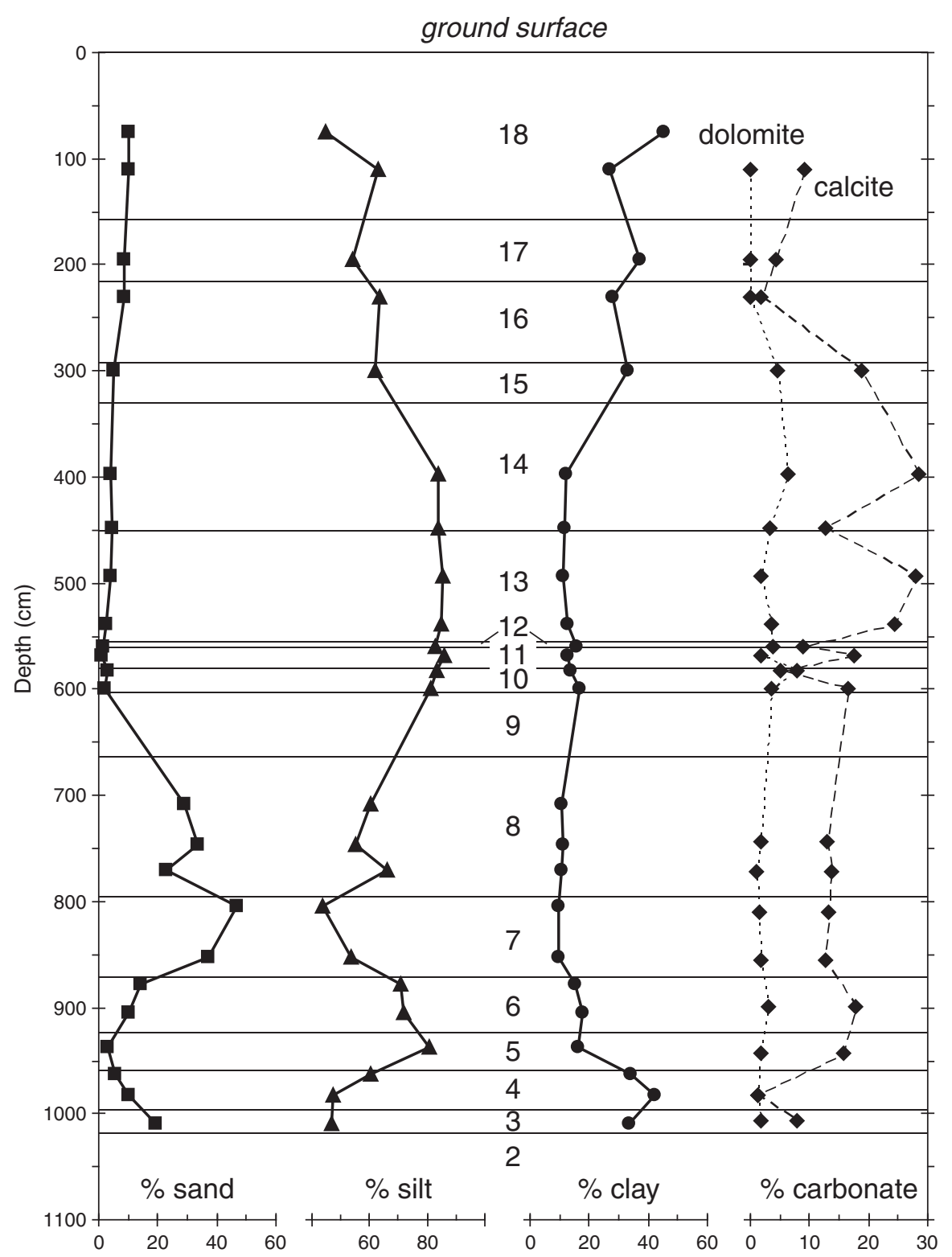

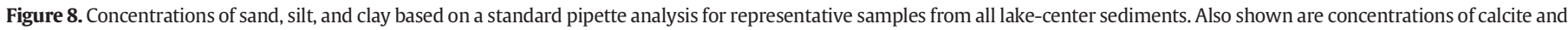
dolomite as determined using a Chittick gasometric device.

thousands of paleontological samples.) Descriptions and detailed photographs of the various near-shore sedimentary units are provided in Lucking et al. (2012). A brief description of the near-shore units is provided here.

\section{Unit descriptions}

The moraine that underlies the sediments dips an average of $\sim 10^{\circ}$ toward the basin center, although dip angles vary considerably and range up to $30^{\circ}$. The upper surface of the moraine is irregular with blocks protruding into the overlying sediments. A $10-\mathrm{cm}$ unit of highly plastic, gray clay interbedded with well-sorted, red sand sits directly on the moraine and correlates with Unit 3 in the lake-center stratigraphy. The interbedded red sands are largely discontinuous but, where present, form alternating bands with the clay.

Overlying the unnamed clay unit is a massive, poorly sorted diamictite called the Basement Red Pebble. This unit is $\sim 1 \mathrm{~m}$ thick and contains abundant matrix-supported, red sandstone clasts, averaging pebble to cobble in size, and grades into the underlying clay across a $\sim 5$ to $10 \mathrm{~cm}$ interval. We are not able to correlate the Basement Red Pebble unit to the lake-center stratigraphic sequence.

On average, $\sim 1.5 \mathrm{~m}$ of massive, organic-rich silt overlies the Basement Red Pebble. This unit, termed the Basement Silt, forms a gradational contact with the Basement Red Pebble, and is both fine-grained and well-sorted, lacking the matrix-supported, red sandstone clasts. The Basement Silt appears to correlate with some combination of units 4-6 in the lake-center stratigraphy, although a lack of diagnostic features does not allow us to correlate the unit any more precisely than this. Sitting above the Basement Silt, the Main Floor is composed of angular to subangular rocks in a coarse sand and gravel matrix. This unit is clast-supported, with clasts ranging in size from a few centimeters to $\sim 1 \mathrm{~m}$ in diameter. In some sections, particularly toward the basin center, the clasts are oriented with their long axis parallel to the bedding plane. Toward the basin margin, the Main Floor thickens and becomes indistinguishable from the till.

Overlying the Main Floor are the Main Floor Red Pebble and Main Silt, consecutively. Although slightly thinner than the Basement Red Pebble and Basement Silt, these two units are nearly identical in 


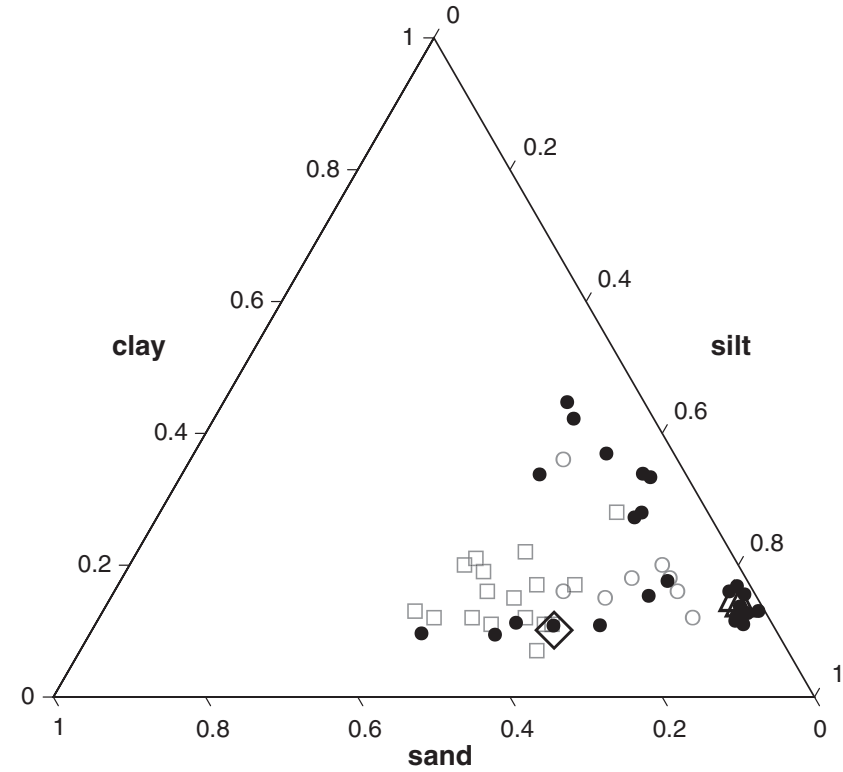

$$
\begin{aligned}
& \text { - ZR samples } \Delta \text { modern dust } \\
& \square \text { Birkeland 1973 } \triangle \text { lowa loess standards } \\
& \text { McCalpin \& Irvine } 1995
\end{aligned}
$$

Figure 9. Ternary diagram showing particle sizes of Ziegler Reservoir (ZR) sediments (filled circles) compared to loess or loess-like sediments at nearby sites (open circles and open squares), loess standards (open triangle), and modern dust collected near the reservoir in 2012 (open diamond). The similar distributions of the various sources suggest that most of the lake-center sediments were transported into the basin via eolian processes.

lithology and appearance to the two underlying units. The Main Silt correlates to the upper part of Unit 7 and/or lower part of Unit 8 based on stratigraphic relations observed at localities 43 and 49 (Fig. 5).

The Primary Debris Flow overlies the Main Silt. This unit is a matrix-supported diamictite with clasts up to $50 \mathrm{~cm}$ in diameter contained within a sand and gravel matrix. The contact with the underlying Main Silt is sharp and characterized by both flame and balland-pillow structures that are present in the top of the Main Silt. The Primary Debris Flow is thickest toward the basin margin where it becomes indistinguishable from the till, and pinches out east of Locality 43.

Overlying the Primary Debris Flow are, consecutively, the Upper Silt and the Beach Silt. Large portions of these units had been removed during the reservoir expansion work before they could be documented. In addition, where they were still exposed, it was difficult to distinguish between them. Both are organic-rich silts with occasional cobble-sized sandstone clasts and abundant fossil logs. At the basin margin, they contain a sequence of fossil logs that are aligned parallel to the paleoshoreline and intermingled with at least two disarticulated but associated mastodon skeletons.

Finally, above the Beach Silt are, from oldest to youngest, the Upper Debris Flow, White Clay, and Upper Red Sand. The Upper Debris Flow is a matrix-supported diamictite unit that is composed of sand, gravel, and large sandstone clasts (up to $\sim 50 \mathrm{~cm}$ ). In contrast, the White Clay is composed of plastic clay with an abundant sand fraction and the Upper Red Sand is a reddish, well-sorted, coarse-grained and massive sand. Contacts between all three units are sharp.

\section{Inferred depositional settings}

The stratigraphy of the near-shore sediments represents an infilling sequence recording predominantly near-shore, subaqueous deposition,

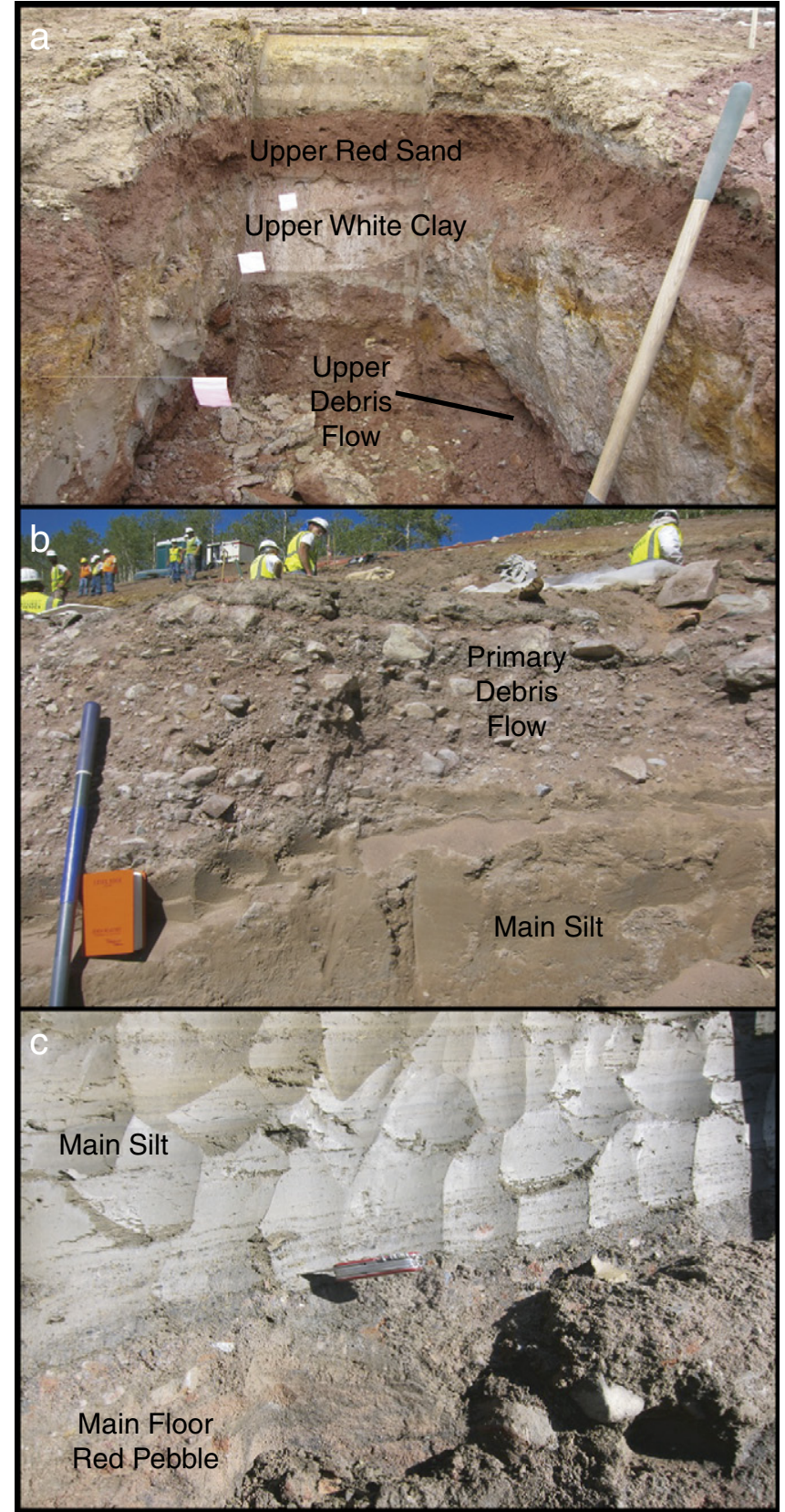

Figure 10. Photographs of some of the near-shore sedimentary units along the eastern margin of the Ziegler Reservoir fossil site. Note the dramatic difference in the appearance of these sediments compared to the fine-grained, lake-center sediments (Fig. 7).

punctuated by intervals of subaerial exposure and moraine slope failures. Just above the basal till, the unnamed sticky clay unit represents initial sedimentation in the lake that took place immediately after the glacier retreated from Brush Creek Valley. Similar to Unit 3 in the lakecenter stratigraphy, this clay unit was likely formed by deposition of rock flour that was abundant in the nearby Snowmass Creek Valley and adjacent areas. The overlying matrix-supported diamictite (Basement Red Pebble) and organic silt (Basement Silt) indicate periods of relatively quiet-water deposition. The diamictite, which thickens toward the basin margin, appears to be the result of amalgamation of a series of minor slope failures within the wave-base zone at the edge of the paleolake.

The overlying diamictite (Main Floor), which contains clasts up to 1 $\mathrm{m}$ in diameter, thickens and coarsens markedly toward the basin 
margin. The unit is clast-supported, its clasts are oriented, and there were virtually no large fossils recovered within the unit. Collectively, this suggests that it was formed by winnowing of slope-wash, possibly during a lake lowering event.

The Main Floor Red Pebble and Main Silt are lithologically very similar, and arguably genetically similar, to the underlying Basement Red Pebble and Basement Silt sequence. Sitting above these units, the Primary Debris Flow appears to have been rapidly deposited as it is composed of matrix-supported and randomly oriented clasts. Moreover, the underlying Main Silt exhibits evidence of soft-sediment deformation, which indicates the Primary Debris Flow formed in a subaqueous environment following slope failure of the surrounding moraine in a single or a few mass-wasting events. The overlying silts (Upper Silt and Beach Silt) and the interfingering and bedded Yellow Brick Road (Unit 10) suggest a continuation of subaqueous deposition following the emplacement of the Primary Debris Flow.

Finally, the Upper Silt and Beach Silt, which contain multiple large logs that are oriented parallel to the strike of the moraine, as well as the Upper Debris Flow, White Clay, and Upper Red Sand, are all indicative of shoreline or near-shore environments. We interpret the Upper Silt and Beach Silt to represent a submerged sequence, immediately adjacent to the wash zone, that probably occurred in no more than 1-2 m of water. The Upper Debris Flow represents a bank collapse into that depositional environment. The White Clay may correlate to Unit 18 and, if so, likely represents deposition of glacial flour in an open lake during MIS 4, although this section was not dated directly. Alternatively, it may correlate to some part of Unit 13 or 14, in which case it would be much too old to correlate to MIS 4. Finally, the Red Sand unit, which is the highest unit in the near-shore sedimentary sequence, appears to represent a beach that surrounded the lake during its final stages.

\section{Discussion and conclusions}

Numerical modeling of the climate conditions required to support the Bull Lake glacier indicates that temperatures were $\sim 5-9{ }^{\circ} \mathrm{C}$ colder than today, depending on the amount of precipitation that is assumed (Leonard et al., 2014-in this volume). Such conditions created a glacier large enough to overtop a low spot on the eastern wall of Snowmass Creek Valley and form a moraine that impounded a small lake at the ZRFS. Multiple lines of evidence, including soil properties, geomorphologic characteristics, and both radiometric and luminescence dates (Mahan et al., 2014-in this volume), suggest that deposition of the moraine occurred at $\sim 155-130 \mathrm{ka}$, near the end of MIS 6 and correlative with the maximum extent of Bull Lake glaciers elsewhere in the Rocky Mountains.

At its inception, the alpine lake was $\sim 10$ m deep near the eastern edge of the basin and shallowed slightly to the west. Over the next $70 \mathrm{ka}$ or so, the lake slowly filled up with fine-grained sediment, mostly silt and clay derived from eolian processes and, to a lesser extent, from sheetwash and overland flow emanating from the adjacent moraine surface (Fig. 11). This slow, gradual buildup was interrupted several times by mass wasting events that occurred along the eastern margin of the lake. These events are represented by poorly sorted, unchannelized slump deposits that contain rocks and debris up to $\sim 1 \mathrm{~m}$ in diameter, as well as most of the large vertebrate fossils recovered from the site.

One of the early hypotheses regarding the origin of the slumps, as well as the abundance of large fossils therein, was known as the "shake-kill-shake-bury" hypothesis. This hypothesis invoked nearby seismic events that could have trapped the animals in a near-shore environment via liquefaction and later moved their bones and the large rocks and debris present in the slump deposits out into the lake via
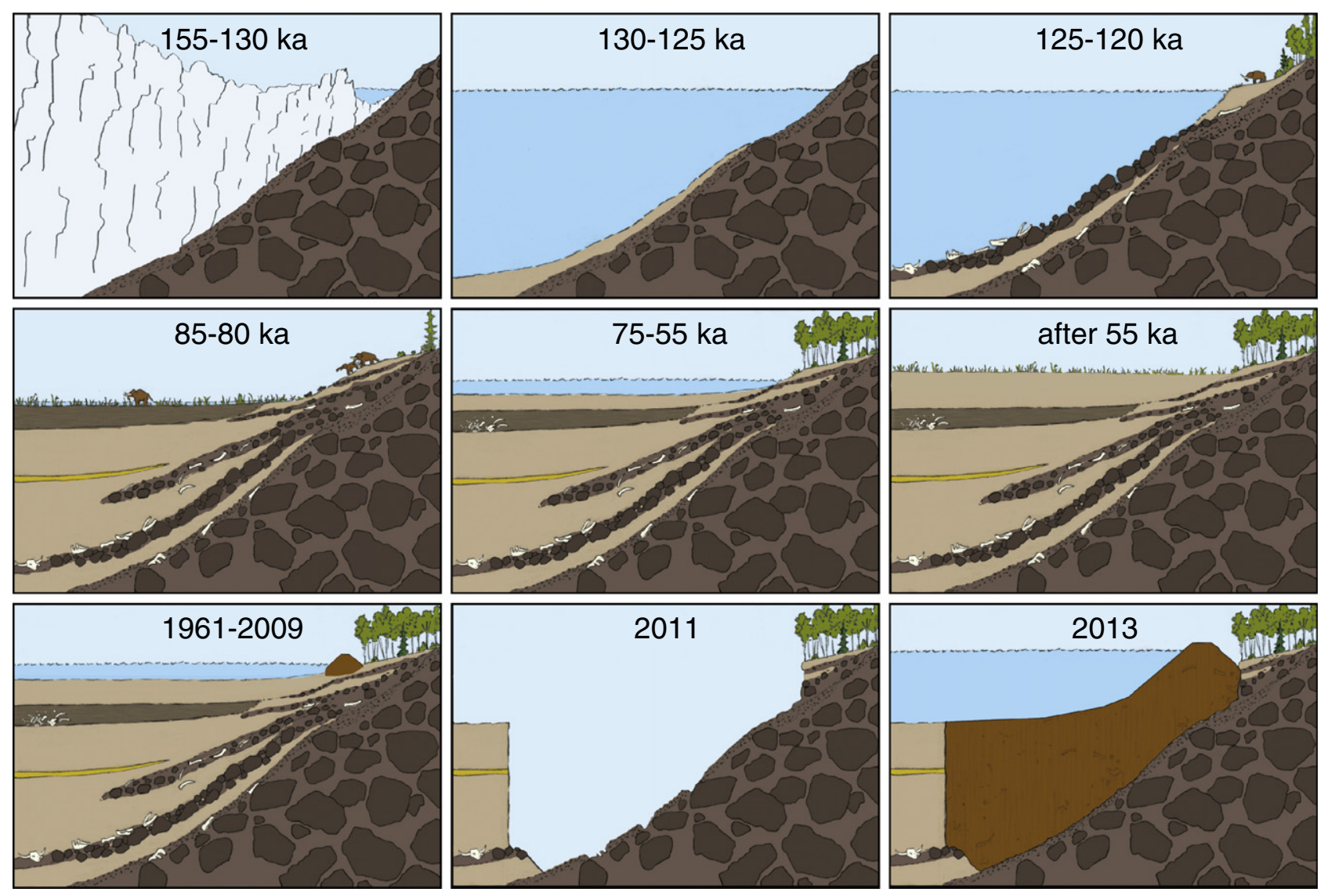

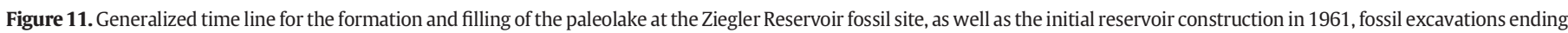
in 2011, and construction of the new earthen dam (after Johnson and Miller, 2012). 
mass-wasting events caused by subsequent shaking. Although we cannot disprove this hypothesis, analysis of both the lake-center and near-shore sediments did not reveal any clear evidence of past seismic activity. Regardless of their cause, the slumps must have occurred at widely spaced intervals when saturated materials could no longer maintain the cohesive forces necessary to prevent slippage. Bones that were scattered about at the surface or in near-shore or shallow-water environments would have become entrained in the rocks and debris, and transported into the lake basin along with the surrounding sediment.

By $\sim 87 \mathrm{ka}$, the lake had become sufficiently filled with silt to the point that it resembled a marsh or wetland more than a lake, although periods of shallow ponding probably followed heavy snow years or sustained precipitation events. Several large vertebrates, including the mammoth originally discovered by Jesse Steele in October 2010, show that water levels had diminished to the point that animals could walk (or attempt to walk) across the basin before becoming stuck in the mud. Open-lake conditions returned between $\sim 77$ and 55 ka when the impoundment was finally breached to the east, establishing ties with the Brush Creek drainage system and creating an alpine meadow in the former lake basin.

The stratigraphy described here captures the general setting of the ZRFS but by no means should it be considered as comprehensive. Additional details that are important to the various paleontologic or paleoenvironmental proxy techniques can be found in other articles in this volume. However, the sedimentology and stratigraphy discussed here provides a framework for those studies and captures the important, large-scale features of the site.

\section{Acknowledgments}

We thank Ronna Bowers, Harland Goldstein, Gary Skipp, and Kenzie Turner for assistance during drilling operations. We thank Paco van Sistine for creating the site location figure. This manuscript benefited from constructive reviews from Eric Leonard, Joseph Licciardi, and Kenzie Turner. Specimens referenced in this paper were collected at the Ziegler Reservoir locality, 5PT1264, under State of Colorado Paleontological Permits 2010-106 and 2011-17. The authors thank History Colorado/The Colorado Historical Society, the Snowmass Water and Sanitation District, and Snowmass Village for their assistance with this excavation. This project was funded in part by the U.S. Geological Survey's Climate and Land Use Change Research and Development Program, the National Science Foundation (\#EAR 1125579), and the National Geographic Society's Committee for Research and Exploration.

\section{References}

Benson, L., Madole, R., Phillips, W., Landis, G., Thomas, T., Kubik, P., 2004. The probable importance of snow and sediment shielding on cosmogenic ages of north-central Colorado Pinedale and pre-Pinedale moraines. Quaternary Science Reviews 23, 193-206.

Benson, L, Madole, R., Landis, G, Gosse, J. 2005. New data for Late Pleistocene Pinedale alpine glaciation from southwestern Colorado. Quaternary Science Reviews 24, 49-65.

Birkeland, P.W., 1973. Use of relative age-dating methods in a stratigraphic study of rock glacier deposits, Mt. Sopris, Colorado. Arctic and Alpine Research 5, 401-416.

Birkeland, P.W., 1999. Soils and Geomorphology. Oxford University Press, New York.

Birkeland, P.W., Shroba, R.R., Burns, S.F., Price, A.B., Tonkin, P.J., 2003. Integrating soils and geomorphology in mountains - an example from the Front Range of Colorado. Geomorphology 55, 329-344.

Bryant, B., 1972. Geologic map of the Highland Peak quadrangle, Pitkin County, Colorado, U.S. Geological Survey Map GC-932, 1:24,000 scale.

Bryant, B., 1979. Geology of the Aspen 15-minute quadrangle, Pitkin and Gunnison Counties, Colorado. U.S. Geological Survey Professional Paper 1073, pp. 1-146.

Bryant, B., Martin, P.L., 1988. The geologic story of the Aspen region. U.S. Geological Survey Bulletin 1-53 (1603).

Hallberg, G.R., Lucas, J.R., Goodmen, C.M., 1978. Semi-quantitative analysis of clay mineralogy. In: Hallberg, G.R. (Ed.), Standard Procedures for Evaluation of Quaternary Materials in Iowa. Iowa Geological Survey, Iowa City, Iowa, pp. 5-22.

Johnson, K.R., Miller, I.M., 2012. Digging Snowmastodon: Discovering an Ice Age World in the Colorado Rockies. Denver Museum of Nature and Science and People's Press, Denver, CO.

Knell, K.L., 2009. Interim findings of geotechnical study, proposed Ziegler pond enlargement, Snowmass Village, Colorado. In: Mock, R.G., Pawlak, S.L. (Eds.), Geotechnical Investigations Report for Ziegler Reservoir, Pitkin County, Colorado. URS Corporation, Glenwood Springs, CO, pp. 125-140.

Leonard, E.M., Plummer, M.A., Carrara, P.E., 2014. Numerical modeling of the Snowmass Creek paleoglacier, Colorado and climate in the Rocky Mountains during the Bull Lake glaciation (MIS 6). Quaternary Research 82, 533-541 (in this volume).

Licciardi, J.M., Pierce, K.L. 2008. Cosmogenic exposure age chronologies of Pinedale and Bull Lake glaciations in greater Yellowstone and the Teton Range, USA. Quaternary Science Reviews 27, 814-831.

Lucking, C., Johnson, K.R., Pigati, J.S., Miller, I.M., 2012. Primary mapping, stratigraphic data and field methods for the Snowmastodon Project, Denver Museum of Nature and Science Technical Report \#2012-04, pp. 1-102.

Mahan, S.A., Gray, H.J., Pigati, J.S., Wilson, J., Lifton, N.A., Paces, J.B., Blauw, M., 2014. A geochronologic framework for the Ziegler Reservoir fossil site, Snowmass Village, Colorado. Quaternary Research 82, 490-503 (in this volume).

McCalpin, J.P., Irvine, J.R., 1995. Sackungen at the Aspen Highlands Ski Area, Pitkin County, Colorado. Environmental and Engineering Geoscience 1, 277-290.

Muhs, D.R., Benedict, J.B., 2006. Eolian additions to the late Quaternary alpine soils, Indian Peaks Wilderness Area, Colorado Front Range. Arctic Antarctic and Alpine Research $38,120-130$.

Tweto, O., 1979. Geologic map of Colorado, U.S. Geological Survey Map, 1:500,000 scale.

Vandenberghe, J., 2013. Grain size of fine-grained windblown sediment: a powerful proxy for process identification. Earth-Science Reviews 121, 18-30.

Ward, D.W., Anderson, R.W., Briner, J.P., Guido, Z.A., 2009. Numerical modeling of cosmogenic deglaciation records, Front Range and San Juan mountains, Colorado. Journal of Geophysical Research - Earth Surface 114. http://dx.doi.org/10.1029/2008JF001057.

Young, N.E., Briner, J.P., Leonard, E.M., Licciardi, J.M., Lee, K., 2011. Assessing climatic and non-climatic forcing of Pinedale glaciation and deglaciation in the western U.S. Geology $39,171-174$ 